\title{
SAMĪRA 'AZZĀM, PIONERA DEL RELATO CORTO PALESTINO
} SAMĪRA 'AZZĀM, PIONEER OF THE PALESTINIAN SHORT STORY

\author{
Clara M. a Thomas De Antonio \\ Universidad de Sevilla
}

\begin{abstract}
Resumen: Samīra 'Azzām (1927-1967) es la primera mujer palestina en alcanzar fama por su maestría para escribir relato corto. Tras revisar su vida, que pasó en el exilio desde 1948, se resumen el contenido de sus colecciones de relatos, sus principales líneas temáticas y sus traducciones al árabe de obras de la literatura universal. Pero la parte principal de este trabajo se va a dedicar a describir y comentar algunos de sus relatos más destacados.
\end{abstract}

Palabras clave: Samīra 'Azzām, Literatura palestina, Relato palestino, Literatura árabe moderna.

Abstract: Samīra 'Azzām (1927-1967) is the first Palestinian woman to achieve fame for her mastery to write short stories. After reviewing her life, she spent in exile since 1948, the content of her collections of stories, its main thematic lines, and her Arabic translations from works of world literature are summarized. But the chief part of this paper will be dedicated to describe and discuss some of its most prominent short stories.

Keywords: Samīra 'Azzām, Palestinian Literature, Palestinian Short Story, Modern Arabic Literature.

La partición de Palestina en 1947 y la posterior creación del Estado de Israel en 1948 tuvieron un efecto catastrófico sobre el pueblo palestino en todos los aspectos, y la literatura árabe en general y la palestina en particular lo van a reflejar. Por otro lado, la voz de la mujer en la sociedad palestina irá tomando fuerza con el tiempo, tanto en el terreno social y político como en el literario, a medida que la mujer vaya saliendo de la "cárcel" ${ }^{1}$ en que la encerraba la tradición. Y en este contexto surge la figura de Samīra 'Azzām.

1 La gran poetisa palestina Fadwà Ṭūqān, en su poema "Detrás de los muros", describe el ambiente familiar y social de la Palestina de su tiempo como una cárcel para la mujer (Thomas, 2008: 517). 


\section{BIOGRAFÍA}

Samīra 'Azzām (1927-1967), narradora, traductora y periodista, destaca en el conjunto de la narrativa femenina de su tiempo. Según Piselli (1988: 93), su vida es la típica de una palestina educada de clase media.

$\mathrm{Su}$ corta existencia ${ }^{2}$ se puede dividir en tres etapas:

- Infancia y juventud en Acre y Hayfa (1927-1948).

Nace el 13 de septiembre de 1927, en una conocida familia de un orfebre cristiano ortodoxo de Acre, una ciudad histórica en la costa mediterránea al norte de Palestina. Allí pasa su infancia y la primera parte de su juventud, cursando la enseñanza elemental en una escuela local, para estudiar luego la secundaria en Hayfa, en el colegio de monjas Takmîlīya al-Rāhibāt.

Por sus cualidades y talento, con 16 años es nombrada maestra en una escuela femenina de Acre en 1943, y dos años después, en 1945, es promovida a directora de dicha escuela. Y es entonces cuando comienza a publicar artículos y sus primeras obras literarias, con el pseudónimo de "La chica de la costa" (Fatät al-sāhil), en Filisținn, conocido periódico de Yafa que se publica entre 1911 y 1967.

Había empezado a escribir en 1942, a los 15 años. Gran amante de la poesía y de la narrativa, su ansia de saber la lleva a forjarse una sólida cultura árabe y occidental, siendo influida por Faulkner, Heminway, Sartre, Camus, Simone de Beauvoir y los novelistas rusos que conocerá a través de traducciones al inglés, así como por los egipcios Naŷîb Maḥfūz y Yūsuf al-Šārūnī o por el iraquí ‘Abd al-Malik Nūrī.

\section{- Exilio por diversos paises (1948-1959).}

Samīra se ve forzada a dejar su país en el éxodo de 1948 -la Nakba-, cuando las milicias judías emprenden acciones que fuerzan a muchos palestinos a dejar su patria, por lo que huye con su familia al Líbano, residiendo varios meses en la aldea de Fālūgā, para luego trasladarse a Beirut. Sin embargo, cada dos años se mueve de país en país, reflejando la vida de una mujer que no podía encontrar un lugar adecuado en el que establecerse. Durante su diáspora de 19 años se traslada al menos 8 veces, principalmente entre el Líbano e Iraq. Además, al ver interrumpidos sus estudios de lengua inglesa por los acontecimientos, los sigue por correspondencia.

Poco después de llegar al Líbano se traslada a Iraq, donde pasa dos años enseñando en una escuela de niñas en al-Hilla hasta 1950, año en que vuelve al Líbano y se dedica a escribir relatos breves para publicarlos en $a l-\bar{A} d \bar{a} b$ y

2 Los datos están tomados de Taha (2010: 51-53), Jayyusi (1992: 26), Barbot (1964a: 149150); Piselli (1988: 93-94), Descamps-Wassif (1999: 29), Ashur (2008: 363), Manzalaoui (1989: 297), Abū Fajr (2012), Iskandar (2011), Farag (2015:86) y http://arabic.jadaliyya.com. 
al-Adīb, así como a traducir obras literarias occidentales al árabe. En 1952 deja el Líbano por segunda vez para ir a Chipre, donde trabaja en la Near East Radio, dependiente de la administración británica, como encargada del programa "E1 rincón de la mujer" (Rukn al-mar'a). Y cuando en 1954 la emisora se traslada a Beirut, Samìra también se traslada allí para seguir trabajando como responsable del programa diario "Con la mañana" (Máa l-șabāhh). Y durante esta etapa publica sus dos primeras colecciones de relatos: Cosas pequeñas (Ǎ̌ya șagìra, 1954) y La gran sombra (Al-zill al-kabìr, 1956).

En 1957 retorna a Iraq para trabajar unos 8 meses en la radio iraquí. Allí conoce a un joven palestino originario de Nazaret, Adīb Yūsuf Ḥusn, y deciden viajar juntos al Líbano para casarse el 24 de diciembre de 1959. De vuelta a Iraq por tercera vez, continúa su carrera en la enseñanza y en el periodismo en Bagdad, y trabaja también en la radio. Samīra da la bienvenida a la revolución iraquí liderada por 'Abd al-Karīm Qāsim en 1958, y ese mismo año acepta una propuesta para trabajar, junto a su esposo, en la radio controlada por el liderazgo de la revolución. Además, escribe para el periódico iraquí al-Sa'b y mantiene una estrecha relación con dos poetas iraquíes pioneros: Badr Šākir al-Sayyāb y Nāzik al-Malāika. Pero en 1959 Samīra y su esposo reciben una notificación ordenándoles abandonar Iraq en 24 horas por su actitud crítica hacia el régimen de al-Qāsim.

- Asentamiento en el Libano y muerte temprana (1959-1967).

En 1959 retornan al Líbano, asentándose en Beirut, donde ella trabaja unos meses de profesora en al-Kullīya al-Āmilīya, para luego conseguir un trabajo en la sociedad Flanklin, empresa de traducción y publicación, emprendiendo la traducción de grandes autores como Pearl S. Buck y John Steinbech. También será responsable de programas destinados al público femenino en la radio libanesa. Además, en Beirut estará activa en el campo literario de esta ciudad tan amante de la literatura, siendo miembro de la Liga de Mujeres Árabes (Laŷnat al-Sayyidāt al-'Arabìyāt), impulsando la radiodifusión palestina, escribiendo para las revistas Șawt al-mar'a y Dunyã al-mar'a y publicando más relatos en otras dos colecciones: Yotros cuentos (Wa-qișaș ujrà, 1960) y El reloj y el hombre (Al-sä́a wa-l-insān, 1963). También empieza a escribir una novela, Sinaí sin fronteras, que no concluirá por la derrota en la guerra de junio de 1967, declarando que ya no tenía sentido lo que escribía. Conmocionada por la derrota sufrida, Samīra trata de volver a Palestina a través de Jordania, pero muere el 8 de agosto de 1967 de un ataque al corazón mientras viajaba en coche en dirección a Ammán. Tenía sólo 40 años. Y será enterrada en Beirut.

Tras su muerte se van a recoger otros relatos suyos en dos nuevas colecciones: La fiesta desde la ventana occidental (Al-ìd mina l-näfída al-garbiya, 1971) y Ecos (Asdā', 1997).Y en reconocimiento a su labor, en 1990 le será concedida a título póstumo la Medalla al-Quds de la Cultura y las Artes. 


\section{PRODUCCIÓN LITERARIA.}

Su papel en el desarrollo del relato palestino está encuadrado, en su principio y su final, por dos acontecimientos esenciales para los palestinos: el establecimiento del Estado de Israel en 1948 y la amarga derrota árabe y la ocupación israelí de Cisjordania y Gaza en la guerra de junio de 1967.

Su obra ${ }^{3}$ puede dividirse a grandes rasgos en dos etapas:

- En la primera etapa, que comprende los relatos escritos en Acre antes de 1948, es decir, en Palestina, Samīra publica en el periódico Filisțin textos breves e historias sentimentales y románticas.

- En la segunda etapa, que abarca los textos escritos entre 1948 y 1967, es decir en el exilio, publica historias más realistas y sofisticadas, y entre ellas material directamente relacionado con Palestina y su gente.

\subsection{Relatos.}

Muchos de sus relatos se han reunido en seis colecciones, mientras otros se encuentran dispersos por diversos periódicos y revistas. En sus primeros relatos se limita a describir una sociedad tradicional, denunciando en especial las costumbres que oprimían a la mujer árabe; pero, ya en el exilio, irá ligando la lucha por la liberación femenina con la lucha por la liberación nacional, al ir tomando conciencia de la situación de Palestina.

Cosas pequeñas (Ǎ̌yả șagìra, Beirut, Dār al-'Ilm li-1-Malāyīn, 1954) es su primera colección. En ella muestra un especial interés por los asuntos de las mujeres, su estatus y sus relaciones con los hombres, o trata de tragedias sociales y humanas con personajes que se convierten en anti-héroes que se enfrentan a serios problemas sin aparentes medios de escape. Pero aún no muestra gran interés en la cuestión palestina.

En La gran sombra (Al-zill al-kabìr, Beirut, Dār al-Šarq al-Ŷadīd, 1956), su segunda colección, examina todos los temas de la anterior, aunque con un tono más realista. De los 12 relatos, sólo dos se refieren a temas políticos asociados con el problema palestino. Los diez restantes se centran en el aspecto social de diferentes figuras, muchas de ellas mujeres, pero lo hace con mayor sofisticación en su caracterización, en el desarrollo de las tramas y en la manera de concluirlas.

Y otros cuentos (Wa-qișas ujrà, Beirut, Dār al-Ṭalî́a, 1960) es su tercera colección. En ella incluye 17 historias y trata de los mismos temas que la anterior: 10 relatos se centran en temas femeninos, y los otros tratan los problemas sociales y los obstáculos que enfrentan los palestinos de la diáspora.

El relojy el hombre (Al-sāa a wa-l-insān, Beirut, Dār al-Ahlīya, 1963), su cuarta colección, contiene 14 relatos en los que se sigue centrando en los mismos temas de mujeres, sociales y político-nacionales. Pero en ellos trata de escribir, por primera vez en su carrera literaria, historias muy breves, un nuevo género

3 Véase la descripción de su producción en Taha (2010: 51-56) y Piselli (1988: 94-95). 
o sub-género experimental. Seis de ellas, sin título específico, son historias "cortas... cortas" (qașira... qașira), como ella las denomina, y tienen de 500 a 600 palabras, lo que hoy se considera qașira ŷiddan. Esta obra le valió el premio de la asociación libanesa Los Amigos del Libro (Așdiqāa al-Kitāb) en 1963.

La fiesta desde la ventana occidental (Al-îd mina l-nāfída al-garbìya, Beirut, Dār al-'Awda, 1971), su quinta colección, se publica cuatro años después de su muerte. En contraste con la colección previa, ésta no muestra cambios destacados ni en temática ni en nivel estético. Incluye 12 historias y 25 fragmentos que tratan del trabajo y los valores nacionales, todos reunidos bajo un único título, "Emociones palestinas", que parecen haber sido escritos inmediatamente tras dejar Acre en 1948.

Ecos (Asdä', Beirut, Bīsān li-1-Našr wa-1-Tawzi', 1997), su sexta y última colección, publicada en el 30 aniversario de su muerte, recoge relatos escritos entre 1945 y 1950 que la autora nunca había publicado antes, y que han sido reunidos e introducidos por Șaqr Abū Fajr. Muchos de los textos que se recogen en esta colección nos dan un claro retrato de los temas y el estilo que usaba en sus primeros escritos.

\subsection{Traducciones.}

Otra de las grandes contribuciones de Samīra 'Azzām serán sus traducciones. Al saber inglés, se beneficiaba mucho de sus lecturas de la narrativa occidental en su lengua original, y usa esa habilidad para mejorar sus propios relatos y, a la vez, establecer nuevas tendencias en la ficción palestina. De 1950 a 1954 traduce 9 relatos del inglés y los publica en al-Adīb. Y de 1955 a 1964 traduce obras maestras de la literatura universal, algunas a partir de versiones en inglés, y libros de crítica literaria o de temas relativos a los medios de comunicación, la educación y la psicología.

Entre esas traducciones, todas ellas publicadas en diversas editoriales de Beirut, destacan: Cándida (Kandīdā, 1955), obra de teatro de Bernard Shaw; Pabellón de mujeres (Ŷanăh al-nisä, 1956) y Viento del Este, viento del Oeste (Rìh al-Šarq wa-rīh al-Garb, 1959), novelas de Pearl S. Buck; Un americano en Europa (Amrīkì fì Ūrübā, 1959), de Sinclair Lewis; El relato corto en América (Al-qișsa al-qașira fi Amrīkā, 1961), de Ray West; Cómo ayudar a tus bijos en la escuela (Kayfa tusā'id abnā'a-ka fì l-madrasa, 1961), de Mary Frank y K. Laurence; El invierno de nuestro descontento, con el título de Cuando perdimos la paciencia (Hìna faqadnā al-șabr, 1962), de John Steinbeck; El relato corto americano (Al-qișșa alamrikizya al-qașira, 1962), de Danforth Ruse; Thomas Wolf: selección de su arte narrativo (Tümäs Wülf: mujtärāt min fanni-hi al-qașașī, 1962), Historias de héroes (Hikāayāt al-abțāl, 1963), de Alice Isabel Heseltine; La edad de la inocencia ('Așr al-baräa, 1963), de Edith Whartou; El arte de la televisión (Fann al-tilifizyün, 1964), de William Kaufman, o Diez relatos de Somerset Maugham ('Ašr qișaṣ liSomerset Mugam, s.d.). 


\subsection{Entrevistas y articulos.}

Ha publicado numerosos artículos sobre diversos temas. Entre ellos destaca "El papel de la literatura en la batalla de Palestina" (Dawr al-adab fì ma'rakat Filisțin, s.d.), en que urge a los escritores palestinos a comprometerse con su realidad estando en contacto con sus compatriotas que tienen que pasar sus miserables vidas en los campos de refugiados. Sus argumentos también los detalla en una conferencia pronunciada en Bagdad en 1965, en que habla del papel de la literatura y los medios de comunicación en la lucha por Palestina, y reta a los escritores palestinos a centrarse en describir a luchadores reales, en describir al pueblo palestino más que la conducta individual de alguno de sus miembros, y hacerlo a diario, no en contadas ocasiones. Además publica entrevistas con literatos árabes ${ }^{4}$.

\section{PRINCIPALES LÍNEAS TEMÁTICAS.}

Sus obras se centran básicamente en tres temas principales: la mujer, los problemas sociales y la cuestión palestina ${ }^{5}$ :

3.1. Los relatos que tratan temas femeninos abarcan más del $50 \%$ de su obra. Samīra es la primera escritora palestina en liderar la "literatura de mujeres", al centrarse en varias generaciones de personajes femeninos y en el papel económico y social que juegan en la sociedad. En todas esas generaciones las mujeres parecen estar intimidadas, victimizadas, aisladas e incapaces de encontrar un camino apropiado para alcanzar su plenitud. Pero la mujer no está sola en las tramas, ni se encuentra un único modelo de mujer: las ansiedades de la madre y la esposa se encuentran con las del adolescente, el combatiente, el huérfano, el vendedor de chicle o la prostituta.

3.2. En los relatos de temática social, Samīra se centra en personajes pobres y marginados, a los que convierte en protagonistas, poniéndolos así en lo más alto de la agenda de la conciencia social. Muchos de ellos son chicos jóvenes forzados por severas circunstancias de pobreza a mendigar en las calles y, en el mejor de los casos, a vender periódicos.

3.3. El tercer tema, la cuestión palestina, es el más escaso en sus colecciones, pues sólo 10 de sus relatos se dedican directamente al problema palestino -aunque en muchos otros siempre hay un retrato de la sociedad palestina de su tiempo-, y con todo juegan un papel clave en volver a dar forma a la identidad palestina, tratando de la experiencia de la diáspora, los horrores del exilio, la nostalgia de la tierra perdida y la esperanza siempre viva del retorno. Sus personajes exiliados evolucionan desde la alienación y la tristeza a la ira y la resistencia.

4 Véase, por ejemplo, su "Entrevista con Mìjā’ îl Na'īma” en 'Azzām (1971: 79-83).

5 Cfr. Taha (2010: 54-55), Ashur (2008: 221), Piselli (1988: 95) y Descamps-Wassif (1999: 29). 


\section{ALGUNOS RELATOS DESTACADOS.}

Dada la amplitud de su obra, nos vamos a ceñir a describir y comentar algunos de sus relatos, a través de los cuales podemos constatar esa variedad de su temática.

Un ejemplo del tono romántico de su primera colección, Ašyä șagìra, es el relato "Hasta ese momento" ${ }^{6}$ sobre el trato dado a una joven casadera según sus posibilidades de atrapar a un novio rico. Anīsa y Šafíqa, mujeres de pocos recursos y expertas bordadoras, quieren casar a su sobrina Suāa, huérfana que tienen a su cargo, con Fahmī, hijo de un acomodado doctor que acaba de llegar al vecindario y que posee una limusina con chófer y una envidiable villa. Las tías habían visto a Su'ād intercambiando sonrisas con este chico en el balcón, y sabían que se había cruzado con él por la calle o en el tranvía, donde él le había pagado el billete. Por ello piensan que podrían casarla con Fahmī, a pesar de la diferencia de clase social, como indica este diálogo entre las tías:

Cuando Šafíqa se quedó a solas con Anīsa [...], ésta preguntó a su hermana: - ¿Es posible?

- Creo que sí... ¿Por qué no? Todo depende de que cause una buena impresión. ¿Está él tan por encima que no podría enamorarse y casarse con ella? Después de todo, es la chica más guapa del barrio. Puede ser pobre, comparada con él, pero eso no es una deshonra. Según he oído, la madre de Fahmī era sólo una enfermera en la clínica de su marido. Nuestra chica está bien criada, sabe cómo comportarse, viene de una buena familia y, por añadidura, está bien educada. Es miembro de la familia de Abū Fāris, y nadie ha sugerido nada deshonroso de ninguna mujer de su familia. Esto exige diplomacia, tacto y discreción; tacto y discreción, eso es todo. Mañana iremos a visitar a la madre del chico (Suleiman, 1990: 185).

Además las tías diseñan toda una estrategia para lograr su aspiración, tratando de convertirla en una señorita, por lo que impiden que Su'ād se dedique, como antes, a las tareas del hogar, y hasta le llevan el desayuno a la cama y le compran ropas elegantes. Un día las tías, tras encontrarse con Fahmī por la calle y saludarse, le invitan a subir a su casa, aunque Su'ād no abre la boca durante la visita. Otro día Layla, hermana de Fahmī, va a encargarles un bordado, y ellas la reciben con los brazos abiertos, ofreciéndose incluso a enseñarla a bordar, lo que ella acepta encantada de tener una experiencia diferente en su vida de lujo; y así se hace amiga de Suẫd, a la que invita a su fiesta de cumpleaños; entonces las tías le compran un vestido y zapatos nuevos para que sea la invitada más atractiva. Su'ād está feliz en este nuevo ambiente y, cuando vuelve, las tías le preguntan ansiosas si ha saludado a la madre y si ha bailado con Fahmī... pues están muy preocupadas porque había en la fiesta una chica rubia cuya madre visitaba todos

6 "Until Such a Time”, trad. de Suleiman (1990: 183-189). 
los días la clínica del doctor, quizás buscando atrapar a Fahmī para su hija... Su'ād, soñando con Fahmī, se deja mimar por su tías, hasta que sus maniobras se desvanecen cuando el joven se va a estudiar a América sin haber expresado su amor por Suād. A partir de ese momento las tías vuelven a tratarla como antes, azuzándola para que se levante temprano y haga las faenas del hogar.

En "Quiero agua"7 se denuncia la importancia que la familia árabe da al nacimiento de un varón frente al de una niña o los prejuicios de la mentalidad popular sobre la limpieza ritual de la mujer. La protagonista es una joven que está interna en un colegio de monjas, ambiente que conoció en su juventud. El relato comienza de noche, con las niñas durmiendo en el dormitorio del colegio y con la protagonista llorando por una carta en que le dicen que su hermano está enfermo.

Farīd era el único varón de la familia, y ella sabía cuánto significaba para su madre, para su padre y para las solteras y ancianas de la familia. Antes de que él naciera, no había captado lo que significaba para una familia ser bendecida con el nacimiento de un niño. No lo había captado hasta que vio sacrificar un cordero en el umbral después de que su tía, trinando de alegría, abriera la puerta de la habitación donde su madre había dado a luz. No lo había captado hasta que vio la sonrisa que estallaba en el rostro de su abuela, una sonrisa que su gran boca no pudo contener incluso cuando empezó a dar profusas gracias a Dios (Suleiman, 1989: 164-165).

La chica se siente culpable porque ha comulgado estando con la menstruación, algo que le ha ocurrido de repente y sin preparación, pues era un asunto tratado con disimulo o burla por quienes la rodeaban. Cuando había estado de vacaciones en su casa, no había hablado con su madre del crecimiento de sus senos, y a menudo oía a las amigas de ésta cuchicheando sobre ella. Además, cuando Salwà, su deslenguada compañera de internado, había descubierto que su falda estaba manchada, se había reído de ella y le había mandado a la Madre Marta para que le dijera que ya no era una niña. Así había descubierto en los aseos esa "cosa vergonzosa", y se sintió muy sola para afrontar este acontecimiento para el que nadie la había preparado. Y se pregunta por qué había nacido mujer. Cuando llega el domingo y ha de comulgar, su vergüenza y culpabilidad de exacerban, pero comulga:

Ella no habría sabido que había una conexión entre "esa cosa" y uno de los sacramentos de la Iglesia si no hubiera oído a una de sus amigas advertirle que no podía comulgar si no estaba ritualmente limpia y pura, pues el mero acto de acercarse al altar en ese estado era un pecado capital en su religión. Ella creía que si revelaba su secreto sería zaherida, porque tal revelación daría a Salwà otra oportunidad para mofarse de ella y condenarla por ser una mujer.

7 “I Want Water", trad. de Suleiman (1989: 164-167). 
¡Imagínate! ¡Una mujer! Y ella había rechazado ponerlo como excusa [para no comulgar] (Suleiman, 1989: 165).

Tras comulgar en ese estado, siente que ha pecado y que su hermano va a morir por su culpa. Imaginando a su familia ante el ataúd de su hermano, es tal su tormento que trata de cambiarlo por su propio ataúd acabando con su vida. Primero piensa en tirarse por la ventana, pero lo rechaza porque quizás no moriría, y eso daría a Salwà el placer de disfrutar viendo su cuerpo destrozado. Luego piensa en tomar un veneno, pero en el colegio no podía acceder al matarratas que su padre usaba en casa. Entonces piensa en el bote de aspirinas que había en su armario:

Ahí estaba el bote. Si se tragaba hasta la última pastilla, seguro que moriría. Por la mañana sería un cadáver tendido en el suelo del dormitorio. Sus amigas de la escuela enmudecerían al verla y la directora llamaría a su madre y a su padre. Otra calamidad para la familia, como si la enfermedad de Farīd no fuera suficiente. Pero ella iba a hacer eso para dar a Farīd una oportunidad de vivir... La muerte de una chica no es lo mismo que la muerte de un chico.

Sus manos estaban temblando y sus miembros tiritaban de frío. Quería agua para tragarse las pastillas. ¿Cómo se las iba a tragar en seco? [...] ¿Dónde estaba el agua? ¿No había una jarra o un vaso en la habitación? [...] ¿Qué líquido podía ayudarla a cambiar su vida por la de Farīd?

Se arrastró hasta la cama y enterró su cabeza bajo el cobertor, tratando de anular el murmullo de las páginas de la carta, que oía cada vez que volvía la cabeza hacia la derecha, con ahogados sollozos entremezclados con la sedienta frase: “QQuiero agua! ¡Quiero agua!” (Suleiman, 1989: 166-167).

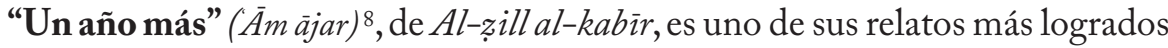
sobre el tema palestino, y fue escrito tras su exilio. Trata de la separación de las familias palestinas tras la Partición y la creación del Estado de Israel en 1948. Los acontecimientos se sitúan en la visita anual de los árabes cristianos de Israel a los Santos Lugares en la Ciudad vieja de Jerusalén, y en especial en la Puerta de Mandelbaum, que era el centro de las reuniones temporales de amigos y de familias divididas. El intercambio de noticias entre ambos lados de la línea de armisticio fijada en 1949 solía hacerse cara a cara sólo una vez al año, cuando a los palestinos de Israel se les permitía viajar a Jerusalén para encontrarse con sus parientes que podían venir desde tan lejos como Beirut, viaje que duraba al menos dos días en los años 50 y 60, hecho que Samīra toma en este relato para exponer otros aspectos de la tragedia palestina.

La protagonista es Umm 'Abbūd, una anciana que realiza un fatigoso viaje hasta la Puerta de Mandelbaum en Jerusalén a fin de encontrarse con

8 “Un año más”, trad. de Ma J. Viguera y M. Villegas (1969: 27-32). “Still another year", trad. de S. Rabie, en Manzalaoui (1989: 297-303). "Une autre année", trad. de Barbot (1964a: 159164). Ver también el análisis de este relato en Suleiman (1991: 160-161) y Ballas (1980: 41). 
su hija Mariam, que debe acudir desde Nazaret, donde vive y que ahora está en el Estado de Israel. La primera parte del relato, donde la autora mezcla hábilmente el humor con la melancolía, se mueve en una espiral de círculos crecientes que consisten en la repetición de una lista de regalos que la anciana lleva consigo y que cada vez se va incrementando con nuevos productos, con lo que va avanzando la historia, a la vez que la protagonista va dando datos sobre sí misma y su procedencia, sobre su hija casada y su familia, y sobre la vida de los palestinos que viven en Israel, lo que constituye el telón de fondo para el anhelado encuentro entre madre e hija (Suleiman, 1991: 160-161).

La anciana viaja en taxi desde Siria para dirigirse a Ammán en Jordania y luego a Palestina. Su penoso viaje entre los dos primeros países, que dura cinco horas, está señalado por los registros en los puestos fronterizos de Deraa en Siria y Ramta en Jordania, separados por escasos kilómetros. En este último la anciana sigue comentando al dueño del taxi lo que le lleva a su hija, la situación de ésta y el tiempo que lleva sin verla:

- ¿También ahí registran?

- Tienen que hacerlo.

- Entonces, hijo, a ver si hay suerte y no nos abren el paquete. Les explicas que le llevo a Mariam...

- Sí, huevos duros, pastelillos de dátiles y piñones iy café!

- También manzanas y algo de ropa; vestiditos para los niños, para Karim, para Elías, y uno rojo para Abdel Nur, mi nieto preferido, y no sé por qué, quizás porque se llama como su abuelo, el padre de Abbud. Nació hace un año, por Navidad, y nosotros lo supimos porque lo dijo la radio; yo no lo oí, pero una amiga me lo vino a contar. ¡Dos veces besé el suelo como agradecimiento a Dios porque ella había salido bien del trance! Tres partos lleva sin que nadie le asista, pues su suegra está muerta, y su madre, lejos... Siete años hace que nos separamos. Se fue recién casada y ya es madre de Karim, de Elías y de Abdel Nur... Siete años, hijo, toda una vida. Nunca ha podido ir desde Nazaret a encontrarse conmigo en Jerusalén. O estaba esperando o criando. Su marido, sí, ha venido una vez; mi hijo Abbud la ha visto y dice que estaba gorda y llena de canas. ¡Y la pobre no tiene por qué tener el pelo blanco todavía! (VigueraVillegas, 1969: 28).

También le justifica al que registra el taxi las razones para llevarle a Mariam y su familia todas esas cosas, pues le han dicho que eran caras y escasas en Nazaret. Luego, de camino a Ammán, la anciana le comenta al chófer datos de su vida pasada:

Nosotros somos de Jaffa. La conoces, ¿̇no? En Daray al-Qalá teníamos una casa y un naranjal. [...] Éramos de lo mejor del pueblo. La casa siempre estaba abierta a todos. Mi marido era el alcalde. [...] El día de la boda de Mariam durmieron en casa veinte personas o más. [...] ¡Ya no queda nada! La casa, los 
naranjos, mi ajuar, los cacharros de cobre... Ahora sólo tenemos dos colchones $\mathrm{y}$ dos pucheros, y una mesa que hizo Abbud antes de irse a las guerrillas. Yo vivo en una habitación... (Viguera-Villegas, 1969: 29).

En la segunda parte del relato, tras aludir a su paso por Ammán, la escena se traslada a la Puerta de Mandelbaum, en Jerusalén, que simboliza la paradoja de la separación y de la reunificación del pueblo palestino. Sin embargo, la separación es más deprimente y permanente que la reunificación en términos de tiempo real y psicológico. Y para algunos, como la anciana, el tiempo va corriendo: ella está allí, pero podría no estar ya el año siguiente. En la Puerta de Mandelbaum la autora nos describe a multitud de refugiados impacientes esperando ver emerger a sus parientes del lado israelí: hijos, hermanos, abuelos, nietos, etc. La anticipación, el amor, la miseria, los nervios tensos, el cansancio, la conmoción, la confusión y otros muchos sentimientos y emociones se entremezclan, elevando sin piedad el sentido de vulnerabilidad de los refugiados. Los círculos en espiral se van haciendo cada vez menores, mientras la presión se va incrementando. Finalmente llega el momento del alivio, pero no para esta anciana: se abren las puertas, dando paso a una gigantesca erupción de las más tumultuosas emociones humanas (Suleiman, 1991: 161). La anciana protagonista, confusa y exhausta, busca febrilmente a su hija entre la multitud, pero sin éxito, y se desvanece:

La búsqueda de los seres queridos, tanto tiempo lejanos, era frenética. Se encontraban unos a otros llorando, se abrazaban, se estrechaban y se lloraba... Una inmensa cantidad de gente emocionada, allá hasta donde alcanzaba la vista; pero Mariam... a Mariam aún no se la veía. ¿Por qué? Quizá no hubieran dejado pasar a los de Nazaret. ¿Cuándo querrán dejarlos? ¿Que ya han pasado? No, si no, ¿dónde está mi pobre Mariam? Si alguno la ve que le diga que su madre la está esperando. ¿La has visto? No es ni alta ni baja, y tiene el pelo castaño... Tiene que estar con su marido y sus tres hijos... ¡Mariam! ¡Mariam! ¡Mariam!...

Cuando recobró el sentido se vio frente a uno de Nazaret. Mariam le había encargado que buscara y saludara a su madre y le dijera, de la mejor manera posible, que su hija se había tenido que quedar cuidando a su marido enfermo. Pero que le prometía acudir sin falta al año siguiente.

Y la anciana, secándose las lágrimas con la punta del mantón oscuro, le respondió:

- Llévales este paquete. La falda, para ella. El jersey, para su marido, y los vestidos, para los niños. El rojo, para Abdel Nur. Llévaselo y dales un abrazo de mi parte. Diles también que, si vivo un año más, vendré sin falta a la cita, aunque tenga que venir arrastrándome... y que, si Dios en su misericordia me llama a Él, moriré con dos penas en el corazón: el dolor de mi patria y el no haber podido abrazar a Mariam (Viguera-Villegas, 1969: 32). 
De Al-zill al-kabir es "Albórbolas" (Zagārīd) 9 , relato que trata del drama de la separación de las familias, representado en el desgarro y la emoción de una madre que, obligada a seguir viviendo en Yafa, no puede asistir a la boda de su hijo en Beirut. Una de las trágicas consecuencias de la guerra de 1948 y el establecimiento del Estado de Israel es la separación de los miembros de un mismo núcleo familiar, divididos entre el nuevo estado y las áreas circundantes. Los padres fueron separados de sus hijos, los maridos de sus esposas y los hermanos de las hermanas, a ambos lados de la línea de armisticio. A veces las aldeas quedaban partidas por la mitad, causando mucha desdicha, dolor y sufrimiento personal. Obtener noticias de los parientes del otro lado de la línea de armisticio, sobre nacimientos, bodas, muertes y otros temas de interés familiar, no era fácil debido a la inexistencia de canales normales de comunicación (Suleiman, 1991: 158-159).

Ŷamil se va a casar en Beirut, y su familia palestina no puede acudir a la boda, pues están separados por la línea del armisticio. Su único modo de comunicación es la radio que transmitía anuncios sobre el nacimiento de un nieto, la muerte de un padre o la boda de un hijo. Así es como Salmà al-Șawwāf recibe por la radio un mensaje que anuncia la inminente boda de su hijo Ŷamil en una iglesia de Beirut:

De Ŷamīl 'Abd Allāh en Beirut para su padre Karīm 'Abd Allāh, su madre Salmà y su hermana Widād en Yafa. Estoy bien y también mi prometida Nadia. Nos vamos a casar a las tres de la tarde del 8 de mayo en la Iglesia de la Señora. Luego viajaremos a Kuwait para trabajar allí. Deseamos tener noticias vuestras. Poneos en contacto por medio de la radio (Suleiman, 1991: 159).

Al enterarse de la boda de Ŷamīl, su familia le contesta por radio, deseándole felicidad, con el corazón lleno de tristeza por no poder acompañarle en ese día ni nunca:

De Karīm 'Abd Allāh, su esposa Salmà y su hija Widād y su marido, para Ŷamil en Beirut: Felicidades por tu boda. Te deseamos lo mejor (Suleiman, 1991: 159).

En este momento interviene el narrador, ofreciendo el siguiente comentario:

Esto es todo lo que pudieron hacer Salmà y Karīm por su hijo Ŷamìl en el día de su boda, aunque habían estado esperando ese momento desde el mismo día en que nació (Suleiman, 1991: 159).

9 "Ululating", traducción parcial y comentarios de Suleiman (1991: 158-160) y DescampsWassif (1999: 29). 
Ŷamìl era su único hijo varón, la fuente de su esperanza y su alegría.Pero estaba a punto de casarse sin que ningún miembro de su familia pudiera estar con él en este día tan especial. Y a medida que se acercaba la hora de la ceremonia, Salmà se imaginaba lo que estaría sucediendo:

En este preciso momento Ŷamīl se estará casando. ¡ $\mathrm{Si}$ pudiera tener alas para volar hasta él...! ¿Cómo puede ser que se case sin que su madre y su padre estén a su lado? ¡Qué solo tiene que sentirse, al no estar a su lado ninguno de sus parientes! ... Los invitados son todos parientes de ella: su madre, su padre, sus hermanos y hermanas y sus parientes más lejanos...(Suleiman, 1991:159).

Salmà envidia que puedan estar todos juntos, y señala cómo en su Yafa natal "el sabor de la alegría ha desaparecido de la vida de la gente" y "la tristeza está marcada en su frente". Estar separada siempre de su hijo ya es bastante malo, pero no poder asistir a su boda es aún peor. Por ello no es sorprendente que la felicidad de Salmà por la boda de su hijo esté inmersa en una opresiva tristeza, que es el sentimiento que trasmite este relato. Samīra 'Azzām es hábil para expresar esa atmósfera usando cortas frases telegráficas cuya capacidad expresiva va más allá de su sentido semántico. Al tiempo trenza con destreza, dentro de este trágico tapiz de miseria y tristeza, un sustancial elemento de cómico desahogo, que sirve para distraer de la atmósfera tan opresiva, a la vez que eleva el sentido de desesperación y tristeza que embarga a los protagonistas. Este elemento lo proporcionan los celos de Salmà hacia la suegra de su hijo, por quitarle el protagonismo en la boda (Suleiman, 1991: 159-160), como señala el narrador desvelando los pensamientos de Salmà, que intenta superar su tristeza con la ironía:

¿Quién en la tierra podría estar cantando por el novio? ¿La madre de la novia? ¿Cómo va a actuar la muy presuntuosa como si fuera la boda de uno de sus propios hijos? ¡ Maldita sea! El escenario es completamente suyo, así que se ha designado a sí misma como la madre de Ŷamil. Si yo estuviera cerca, le habría parado los pies y habría frustrado su ambición. ¡Sé muy bien cómo son las suegras de los novios! (Suleiman, 1991: 160).

Así ella puede jugar mentalmente su papel como madre reconocida del novio, y a la vez escapar del intenso dolor que envuelve su existencia. Este intento de Salmà de escapar es indicativo de la hondura de su tristeza y desesperación. Tragedia y comedia interactúan en este relato, al aligerar por la comedia la cruda realidad y dar a la tragedia una sensación de agudo patetismo (Suleiman, 1991: 160).

En "Lágrimas en venta" (Dumū' li-l-bay)"10, de Al-zill al-kabìr, Samīra hace un soberbio tratamiento de la reacción de una plañidera que llora, vela y

10 "Larmes a vendre", trad. de Makarius (1964: 309-314). 
lanza las lágrimas por otra gente, pero es incapaz de derramar una sola lágrima cuando muere su única hija. La narradora de la historia es una chica que acude a entierros y bodas para sentir fuertes emociones, especialmente si la plañidera Jazna actuaba en el evento, pues en las muertes ofrecía una imagen estridente contrapuesta a la imagen alegre y chispeante que ofrecía en las bodas. Jazna iba recolectando lo que le pagaban en ambos servicios para su única hija, Mas'ūda, a la que esperaba casar algún día. Al final de cada boda las mujeres le deseaban que pronto pudiera alegrarse con el casamiento de Mas'ūda, pero el destino no la permitió conocer esa alegría, pues un verano a su hija la mataría una epidemia de tifus, epidemia que había dado mucho trabajo y ganancias a su madre. La narradora acaba el relato describiendo, por boca de la joven espectadora, el desconcertante comportamiento de Jazna ante la muerte de su hija:

Llevada por la curiosidad y la compasión, fui a casa de Jazna con el grupo de mujeres que iban a devolverle un poco de lo que le debían en llantos y lamentos. [...]

Yo buscaba ver el rostro de Jazna por encima de las cabezas, y mi sorpresa fue grande al ver que ella no lloraba. Triste, silenciosa, miraba fijamente al suelo en un rincón de la habitación. No se había liado la banda negra en la cabeza, no había teñido de azul su rostro, no se golpeaba las mejillas, no se desgarraba los vestidos...

Por primera vez me encontraba ante una persona que no simulaba sus sentimientos. Estaba viendo el rostro de un ser que sufría y que estaba a punto de morir. Dolor mudo que sólo conoce quien lo ha probado. Algunas mujeres quisieron sollozar y lanzar gritos. Jazna las miró con asombro, como si reprobara esas manifestaciones, y ellas se callaron, desconcertadas por su actitud. Cuando los hombres fueron a levantar el cuerpo de la pequeña Mas'ūda, la única criatura que la había dado ocasión para expresar sentimientos no simulados, Jazna no lanzó aullidos, ni desgarró sus vestidos, sino que les miró con ojos extraviados y les siguió alelada mientras se dirigían a la mezquita y luego al cementerio. Allí se limitó a tenderse en la tierra y colocar la cabeza en el suelo, siguiendo durante horas echada sobre ese polvo al que había sido confiado ese cuerpecito. La gente volvió del funeral haciendo toda clase de cábalas sobre Jazna. Unos sostenían que se había vuelto loca o que actuaba como los cuerdos; otro decían que ya no le quedaban lágrimas que verter al haberlas gastado en los entierros de otros. ${ }_{j} E$ incluso hubo quienes dijeron que no había llorado porque no iba a recibir nada!

Y fueron pocos los que comprendieron que Jazna no había conocido el dolor hasta el momento en que había dejado de comerciar con sus lágrimas (Makarius, 1964: 313-314). 
En "Destino", de Al-zill al-kabir,11 la autora denuncia los matrimonios concertados por los padres. Trata de una joven que ha de someterse a un matrimonio acordado al modo tradicional y al que no se ha negado, al no encontrar razones de fuerza para oponerse a ese "destino" de toda mujer oriental ni oportunidades para que las cosas cambiaran. Ella no estaba buscando novio, y admiraba a un primo con el que podía mostrar su personalidad, pero no lograba conectar con su futuro marido, opuesto a sus gustos románticos. Todos estos sentimientos le pasan por la cabeza en el instante de su boda; en el umbral de la iglesia en que va a casarse, su padre la entrega a su futuro marido, y ella, con la cabeza baja, comprende su triste realidad:

Ella había venido a jurar ante Dios y los hombres, ante ese hombre que estaba de pie a su lado, ser una esposa fiel. [...] ¿Era eso lo que ella quería verdaderamente? [...]

Dividida entre el "sí" de conveniencia y el "no" que le quemaba los labios, para expresar su debilidad ante esa extraña fuerza de su madre y sus amigas ¡había que apelar al Destino! Antes, en el colegio, había excluido esa expresión retrógrada de su vocabulario [...]. Ella, al menos, no era de esa escuela del Destino. El Destino no es más que opio para la voluntad [...].

Pero, ¿podía de verdad rebelarse contra el Destino, que hasta entonces le había impedido la menor resistencia, la menor prueba de su existencia y de su libertad? Lo más asombroso es que no diría "no". ¿Por qué? En el "sî" había una voluntad positiva en que se encuentra un espíritu de aceptación, de abandono, de deseo. Pero su "sí" no tendría ninguno de esos valores positivos. Sería "sí”... y nada más (Barbot, 1964: 121-122).

A continuación la joven va recordando el modo en que sus padres habían concertado su matrimonio con un hombre al que desconocía, y señala el modo de pensar de éstos tan ajeno a sus propios deseos:

Su padre tenía una concepción anticuada de la vida. No podía imaginar nada mejor para su hija que lo que él le ofrecía: que se contentase con comer hasta hartarse, hacer visitas, recibir a los parientes o a algunas amigas, y que se muriera de aburrimiento si a él le apetecía que lo hiciera, mientras jugaba al tric-trac con uno de sus viejos amigos, con ella sentada a su lado...

$\mathrm{Su}$ madre pensaba igual. Sus criterios no eran diferentes. Cercana a los cincuenta años, su única preocupación era encontrar el tranquilizador sostén de un marido para su hija. Ante todo quería que éste fuera rico. El dinero representaba a sus ojos un mobiliario confortable y la fachada social indispensable.

Pero ella, su hija, quería un marido totalmente diferente.

11 "Destin des femmes", trad. de Barbot (1964: 121-128). "Fate", trad. de Suleiman (1989: 142-148). 
Quería que fuera un poco mayor que ella. Sabría de memoria mil poemas de amor. Le gustarían sus acuarelas. Aceptaría ceñirse un delantal para ayudarla a hacer un pastel de naranja o una tortilla de patatas. Y la abrazaría cada diez minutos. Así se representaba ella al "hombre de su vida" (Barbot, 1964: 125).

Pero ése no es el hombre elegido por sus padres, que habían decidido casarla al modo tradicional. Y ella, a pesar de sus dudas y reproches, siente que no tiene más remedio que aceptarlo por esposo. Aún así, en el momento preciso de responder al sacerdote, no acepta esa boda, aunque su muda negativa será inútil:

Un segundo de descuido, y la fatídica palabra saldría, y toda esa pesadilla acabaría: "No quiero, no quiero". Dominada por su turbación, por su fatiga y por su emoción, se puso a repetir esas palabras, a susurrarlas. Pero su grito mudo no lo escuchó nadie. Ni los sacerdotes ni los asistentes. Ni el hombre que estaba a su lado. Un clamor inmenso la había asaltado y subía por la nave, mientras los labios de la gente que sellaban su unión cantaban: "De gloria y de honor el esposo la ha coronado" (Barbot, 1964: 128).

En "La Gran sombra" (Al-zill al-kabirr) ${ }^{12}$, que da título a su segunda colección, la autora describe las inseguridades de la mujer árabe en su relación con los hombres. El relato comienza con una joven culta, deseosa de hallar un hombre que estuviera a su altura, y que no sabe cómo vestirse para acudir a la casa de un profesor que acababa de conocer y parecía reunir las condiciones:

Ante el lío multicolor de su armario le asaltaron las dudas. Pero, al elegir un traje para la ocasión, prefirió no soñar más que en el derecho a la igualdad en la existencia, que era lo esencial de su última lectura, un libro de sociología. [...] Con su intuición femenina, había sentido que una visita a un hombre que vivía solo podía poner en duda sus móviles de acuerdo con las conveniencias y la psicología elemental. Durante un instante dejó caer la percha, pero se repuso, sostenida por su confianza en sí misma [...]. Esa idea le devolvió el coraje. Y eligió su modelo más femenino, se vistió y partió con paso firme hacia su cita (Barbot, 1964: 115).

Sin embargo, sigue dudando sobre las razones que la llevan a esa cita. A la vez va recordando una anterior experiencia amorosa que la había llevado a replegarse sobre sí misma, a adoptar la mentalidad de una sexagenaria y a refugiarse en la lectura:

Ya no era una mujer. [...] Tan sólo deseaba afirmar su libertad, reencontrar su facultad de pensar y probar al otro que no había sido más que un azar en su vida, un miserable azar. Ella para nada podía aceptar subordinar sus ideales a simples azares.

12 “La grand ombre”, trad. de M. Barbot (1964 : 115-120). 
Pero no podía seguir viviendo así. Amaba demasiado la vida y se preparaba para una misión de la que aún ignoraba las mínimas premisas Su propio vacío la aterraba. Era la imagen de la nada. [...] Debía, ante todo, cambiar de vida. [...] Esta vez debía evadirse de las normas, escuchar a su corazón, pero también evaluar al otro en su justo valor. [...] No quería desperdiciarse, dar un gran amor a un ser común que no valiese la pena. No tenía incluso necesidad de amar: le bastaría con alcanzar su plenitud dedicándose a un ser sublime (Barbot, 1964: 116-117).

Recuerda cómo, dispuesta a cambiar de vida, frecuentaba diferentes círculos hasta que por fin apareció esa persona cuando asistió a una conferencia. El orador le había parecido elegante, atractivo y de pensamiento profundo. Desde ese día ella se dedicó a leer sus obras y a participar en las discusiones, consciente tanto de su inferioridad intelectual frente a él como de la fecundidad de cada instante pasado a su lado. $Y$, aunque él recibía visitas femeninas en su casa, ella se pregunta por qué estaba soltero a los 40 años, para concluir:

En Francia, donde él había pasado una parte de su vida universitaria, había conocido muchas mujeres, que reunían en sí a la amante y a la compañera de vida. Pero aquí, en Oriente, todas las mujeres que conocía dudaban de sí mismas (Barbot, 1964: 118).

Seducida por este hombre, se las había arreglado para que la invitase a su casa, donde vivía solo. Pero no quería que la tomase como una simple muñeca, sino como una mujer cuyo capital no se limitaba a unos ojos bonitos. Al llegar a su casa, él la hace sentar en un sofá, pero ella observa el lugar sin poder decir palabra ni actuar como había previsto. Entonces él murmura:

"¿De verdad has venido a hablar de filosofía? ¡Para qué molestarte con las sutilidades que esconden mis libros! Si me lo permites...”

La tomó dulcemente por la nuca y depositó un beso en sus labios. Ella se levantó de su asiento y huyó presa de una furiosa incertidumbre, incapaz de saber si la escena la había irritado o llenado... (Barbot, 1964: 119).

En su huida le da vueltas a la actitud de ambos: no sabía si en realidad ella estaba buscando ese beso, y tampoco le había gustado la falta de romanticismo del hombre al que tanto había idealizado. En su mar de dudas, la narración concluye con estos párrafos:

Desde hacía mucho tiempo ella había aprendido por experiencia a ver fundirse sus relaciones con todas las cosas en la gran sombra proyectada por su ser sobre el resto de la existencia. Éste era su punto flaco...

No sabría decir si era vanidad o no. Así que, con una pálida sonrisa, se secó las lágrimas y se hundió en la noche que caía (Barbot, 1964: 120). 


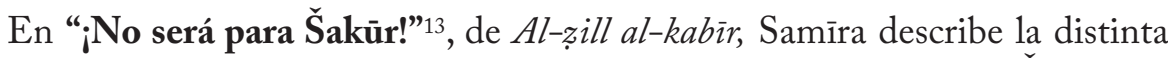
reacción ante la muerte de un hijo o la de personas ajenas. Abū Šakūr, un fabricante de ataúdes, se había ido curtiendo ante la muerte. Había aprendido el oficio con el marido de su tía, que le había dicho el primer día al verlo temblar sin atreverse a entrar en la tienda de ataúdes:

- Vamos, rapaz, ¿qué te pasa? ¿'Te da canguelo? Entra, que no te vas a morir hasta que te llegue la hora. $\mathrm{i} Y$ si te mueres, el mundo perderá poco con un asno de tu ralea! ¡Entra, te digo!

Tragando saliva, había entrado. Desde ese día, había ligado su vida a los ataúdes de la tienda funeraria. Y, al irla frecuentando, se había endurecido. Más aún, su visión lo dejaba impasible, y su macabro símbolo no turbaba sus noches. [...] ¿Acaso había temido huir de la casa familiar un día en que su padre le había maltratado, refugiarse en la "tienda", como él decía, y pasar la noche acurrucado en un ataúd? De hecho, veía las cosas con mucha naturalidad y sensatez. Nuestra vida en este mundo no es más que un breve periplo que al final nos deposita en uno de estos ataúdes negros, blancos o amarillos. ¿No es ridículo ver a los hombres rehusar mirar de frente a una realidad de la que no pueden huir? (Barbot, 1964a: 166-167).

Desde entonces había pasado toda su vida fabricando esos macabros objetos de todos los tamaños y colores, tanto para cristianos como para musulmanes:

Sí, durante 25 años, al alba de cada mañana había abierto su tienda que le daba de comer a él y a los suyos. Cada mañana entraba despreocupado en su taller para tomarse tranquilamente su café mientras impartía órdenes a su aprendiz: "Pon a un lado el ataúd negro de clavos plateados y quítale el polvo. He oído que Abū Ŷubrān está peor. Me parece que no van a tardar en venir a encargar un ataúd. ¿No crees que éste es el más conveniente para alguien que deja en la tierra cien mil libras, dos casas en la montaña y un gran almacén en la ciudad?". Otras veces, sentado en el umbral de su taller, veía pasar a la gente que, sin quererlo, se ponía en guardia: unos se volvían hacia él con curiosidad, $\mathrm{y}$ otros -sobre todos los viejos y las viejas- se santiguaban maquinalmente al pasar (Barbot, 1964a: 166).

Pero, cuando su hijo Šakūr, un adolescente fuerte como un caballo, enferma de fiebres tifoideas, todo cambia. La angustia devora a sus padres. La madre deambula desamparada en torno a su lecho o se refugia en un rincón rezando ante el icono de la virgen y poniéndole velas...El padre no puede parar quieto y, cuando va a su taller, no puede dejar de mirar con horror los ataúdes diciéndose que eran para todos menos para los de su casa: “iiNo será para Šakūr!!”. Además, su esposa promete a la Virgen que su marido dejará sus ataúdes si tiene piedad de su hijo único. Abū Šakūr cree que, por su hijo, debe cumplir esa promesa y

13 “Il ne sera pas pour Chakour!", trad. de Barbot (1964a: 165-170). 
dejar de comerciar con la muerte. Y, tras alquilar un nuevo local donde fabricaría sillas y camas, pasa por el taller, y estalla al ver el maldito ataúd amarillo de sus pesadillas:

La tapa estaba separada, y se podía adivinar el emplazamiento de la cabeza... sombría boca abierta que esperaba... No. Era imposible. ¡No será para... para él! ¡Jamás será para él! ¡Ni para nadie! Entonces se precipitó como arrebatado por una locura devastadora. El odio que crispaba su puño redoblaba sus fuerzas y, empuñando un hacha del fondo de una caja, se lanzó a vapulearlo. Y, tras haberlo reducido a astillas, las esparció con patadas vengadoras (Barbot, 1964a: 170).

En "Desde lejos" (Min ba ìd), de su tercera colección, Wa-qișaș ujrà, Samīra denuncia los perjuicios que sufre la mujer palestina, describiendo cómo una honrada mujer se ve forzada a prostituirse como última opción para sobrevivir en un mundo que la discrimina por su identidad palestina y por su sexo y, por tanto, es doblemente víctima, expuesta a la ira de su sociedad y a la hipócrita explotación de los hombres. Un joven palestino, estudiante de Medicina, tipifica la hipocresía del hombre árabe, que no huye del placer que le ofrece la prostitución, mientras al mismo tiempo se distancia públicamente de ella. Como víctima que él mismo es, debería ser plenamente consciente del efecto humillante de la victimación y la explotación, y esta conciencia, e incluso empatía, debería alejarle de cualquier impulso para explotar a otros, incluidas las mujeres. Pero la mujer apenas cuenta en la conciencia del típico hombre árabe, salvo como objeto de explotación que, en este contexto, no es reconocida por lo que es, un acto inmoral y repugnante, sino que es vista como algo normal en su sociedad machista (Suleiman, 1991: 155-156).

De Wa-qișaș ujrà es "En el camino a las Albercas de Salomón" (Fì l-țariq ilà Birak Sulaymān), un relato lleno de simbolismo y esperanza. Se sitúa en la guerra de 1948, cuando Ḥasan, un maestro de aldea, trata de defender su tierra contra una fuerza judía muy superior. Solo, con su viejo rifle, logra detener su avance, pero por poco tiempo, pues se le acaba la munición y tiene que marcharse. Entonces huye con su mujer y su único hijo, 'Umar, hacia Las Albercas de Salomón en las afueras de Jerusalén. Pero su hijo es herido y muere, y él lo entierra bajo un árbol cuyas ramas están bañadas por la luz de la luna (Suleiman, 1991: 157):

Depositó a su hijo en la tierra. La luna se estaba poniendo y se había vuelto roja, como si el sol estuviera saliendo por el oeste, y el cielo estaba cubierto de una extraña luz como de alba. Desde allí pudo ver los tejados de las casas planas de la plaza de las Albercas de Salomón (Piselli, 1988: 97).

Esta escena está envuelta en una atmósfera de tristeza y derrota, pero también intenta expresar un sentido de amor y esperanza: el maestro "deposita” a su único 
hijo en la tierra de sus seres queridos, sembrando la semilla de la esperanza en el futuro que el árbol y la luz de la luna simbolizan (Suleiman, 1991: 157).

En "El pan del sacrificio" (Jubz al-fida’’) ${ }^{14}$, también de Wa-qișaṣ ujrà, vuelve al tema palestino con un relato simbólico: la muerte de una joven enfermera, Suâd, que en la guerra de 1948 se dedica a cuidar a los heridos y a auxiliar a los compañeros palestinos que han huido de sus casas y llegan en torrente a Acre para evitar el intenso bombardeo que sufren sus aldeas y ciudades. Su'ād es descrita como una mujer de gran coraje y enorme fortaleza, que se niega a dejar Acre durante un fuerte ataque, incurriendo en la ira de su hermano que la presiona para que se vaya. Un día se dirige a primera línea para llevar provisiones a los defensores, que no han recibido víveres desde hacía varios días. Pero ésta será su última misión, porque es mortalmente herida y muere unas pocas yardas antes de llegar a la fuerza de defensa, empapándose las barras de pan que lleva con la sangre de sus tiernos años. Pero no muere en vano. Su amado Rāmiz, que está a cargo de la fuerza de defensa, recupera el pan mojado con su sangre para alimentar a sus hambrientos hombres. Este acto da a su compromiso con Palestina un nuevo significado: ya no es un compromiso con el ideal meramente abstracto de amor a la tierra, sino que está alimentado por la memoria tangible de la sangre de los caídos en la batalla por su propia patria. Su'ād sacrifica su vida por un ideal de libertad, pero su muerte no marca el fin del proceso, sino el inicio de uno nuevo de regeneración y compromiso (Suleiman, 1991: 157-158).

La historia -basada en un hecho real- comienza cuando el guerrillero Ibrāhīm tiende la pipa de tabaco a su compañero Rāmiz, que llora en las barricadas recordando aquella noche de intenso frío en que la había conocido, cómo se había enamorado de ella y cómo había muerto. A Rāmiz le habían ordenado guardar el pequeño hospital de la Legión Árabe establecido en una casita de la ciudad de Acre. En sus ocho camas había hombres heridos en la batalla entre la colonia judía de Naharīya y las aldeas árabes de los alrededores de Acre. Cuando estaba de guardia, muerto de frío, aparece ella, con uniforme blanco de enfermera, y le pregunta si quiere una taza de té para calentarse. Se lo toma sin apenas hablar, y a la noche siguiente ella le vuelve a traer su taza de té. Entonces él le pregunta su nombre, y se queda sorprendido al oír de nuevo el nombre: Su'ād.

Días antes el Comité de Mujeres de Acre les había regalado unos jerseys de lana hechos a mano y mantas para la Legión Árabe. En el bolsillo de cada jersey había una tarjeta con el nombre de la joven que lo había tejido y unas palabras de ánimo. Él aún guardaba la suya. La palpó, la sacó, encendió una cerilla y leyó las palabras "Sưâd Wahb̄̄” y debajo: "Que este jersey sea usado por un héroe" (Jayyusi, 1992: 391).

14 “Bread of Sacrifice”, trad. de K. Piselli y D. Davies, en Jayyusi (1992: 389-399). 
La tercera noche Rāmiz va al hospital, y ella le lleva a ver al herido Ḥasan para que le cuente detalles de la batalla. Éste bromea con la severidad de Suāâ, que no le deja fumar... pero la alaba cuando Rāmiz le pregunta si es buena:

- ¿Buena? Es la mejor de todas. Es mejor que mi anciana madre. Siempre está por aquí, dando a uno algo para beber, a otro algo para comer, y respondiendo a los timbres que suenan en todas las habitaciones. Y, cuando tiene un rato libre, puedes verla sentada junto a la puerta haciendo punto.

- ¿Haciendo punto?

Entonces recordó su jersey. (...) Y abriendo el abrigo para mostrarlo, se volvió hacia ella diciendo:

- ¿Reconoces este jersey?

- Sí. Así que has conseguido uno...

- ¿Es que no lo merezco? Aún tengo la tarjeta. Así siempre recordaré mi deber de comportarme como un héroe (Jayyusi, 1992: 392).

Cuando los enfermos sanan y se vacía el hospital, Rāmiz vuelve a su trabajo de adiestrar reclutas, y pasa varias semanas sin verla. Pero piensa mucho en ella y considera ese jersey como un tesoro. Otro día la ve por la calle y quedan en verse. En la cita charlan de la situación con las colonias judías, y ella le pregunta:

- ¿Tienes miedo?

- Soy cauto. No va a ser fácil. Creo que los judíos han estado almacenando gran cantidad de armas en sus colonias. Hemos descubierto muchas cosas.

-¿Has ido allí tú mismo?

- Sí, solía ir mucho antes de que las relaciones se tensaran. Ahora no puedo ir. Estoy en su lista negra.

Vio cómo ella le observaba, cómo sus labios se separaban y una mirada de determinación brillaba en sus ojos: “¿Sabes? -le dijo- Estoy empezando a pensar que eres algo así como un héroe (Jayyusi, 1992: 393).

Era primavera, estación muy hermosa en Palestina. Y esa primavera Rāmiz conoció el amor y la guerra, dando el primero sentido a la segunda. La guerra no era simplemente un enemigo al que matar, sino la afirmación de la vida de la tierra y la mujer amadas:

En los ojos de Su'ād vio toda la esencia de Palestina. Vio la imagen de un hogar feliz para él, de una esposa que le daría jóvenes héroes y con su amor le daría sentido a su existencia (Jayyusi, 1992: 394).

Los días siguientes la imagen de su amada se mezcla con las noticias de los periódicos sobre las batallas que se estaban produciendo en Palestina y sobre el heroísmo de su pueblo. E1 hecho más importante fue la caída de la ciudad de Hayfa (23-4-1948), que los británicos habían abandonado antes de lo previsto. El terror se apoderó de la gente, y Acre se llenó de refugiados hambrientos 
o heridos que reclamaban auxilio. Rāmiz ve a Su'ād entre las decenas de voluntarias que los socorren. Una noche ella llama a su puerta llorando porque había discutido con su hermano, que había decidido marcharse con su familia al Líbano, y ella quería ser la última en abandonar Acre. Y Rāmiz le pregunta:

- ¿Has hecho eso por mí?

- No, no por ti -dijo ella bruscamente-. Sí, te amo, es verdad. Pero tú no lo eres todo (Jayyusi, 1992: 395).

Luego Rāmiz va a la ciudad y no sabe cómo reaccionar al ver docenas de coches saliendo de ella a toda prisa. Una semana más tarde la ciudad de Acre se queda vacía. Sólo quedan en ella los combatientes, un puñado de enfermeras dispersas entre varios hospitales y los refugiados de Hayfa. Ya no hay tiempo para más encuentros con Suâd, pues de día él tiene que recoger armas y municiones por las aldeas vecinas, y tiene que pasar las noches en la barricada con otros cinco compañeros, como le había encomendado el Comité Nacional de Acre. Pero un día la vuelve a ver llevándoles una cesta de provisiones. Rāmiz le ruega que no vuelva a hacer una locura tan peligrosa, pero ella vuelve a hacerlo repetidas veces, hasta que un día es alcanzada por una bala y muere en sus brazos. Él no puede creer cómo, en un solo instante, había acabado todo. La entierran en la colina y ponen una bandera sobre la tumba de su heroína. A partir de entonces, ya no reciben provisiones. $\mathrm{Y}$ el hambre va debilitando a este comando, que está exhausto. La única comida que les queda son los panes que ella les había llevado y que se habían empapado con su sangre. Tras negarse a alimentar a sus amigos con la sangre de Su'ād, por fin Rāmiz comprende que debía hacerlo para mantenerse vivos y luchar. $Y$ recordando a un sacerdote ortodoxo impartiendo el cuerpo y la sangre del Mesías, se levanta, seguido por los ojos de sus cinco compañeros:

Con las manos temblando, cogió la cesta, la abrió, y se llevó el pan a los labios. Luego se acercó a sus compañeros, cayó de rodillas y distribuyó los panes diciendo: "Comed... Suād no habría querido que muriéramos de hambre" (Jayyusi, 1992: 399).

Como cristiana, Samīra articula simbólicamente aspectos de la tragedia palestina con su religión. La muerte de Suāa y su significado puede considerarse como una recreación simbólica de la muerte violenta de Cristo, que es conmemorada en la eucaristía con pan y vino. Ambos son actos de liberación en los que sangre y sacrificio se mezclan para crear una unidad de visión que transciende el tiempo y el lugar. Cristo es la víctima, pero triunfa a través de la sangre y el sacrificio. Su momento de máxima debilidad se convierte en su momento de mayor fuerza. Su sangre se convierte en la inexorable fuente de vida y regeneración, como hace con la escasa provisión de pan con la que alimenta a 
las multitudes. Del mismo modo, al morir Suâd, el pan se moja con su sangre, que los defensores comen en una especie de comunión para mantenerse y regenerar su compromiso para lograr la liberación de su pueblo oprimido y su tierra amenazada (Suleiman, 1991: 158).

En "Los enemigos" 15 , de Wa-qișaș ujrà, se centra en la lucha fratricida por la vida, denunciando un sistema económico y social incapaz de satisfacer las necesidades de la gente. El protagonista es un hombre, casado hace cinco años, que busca empleo desesperadamente para poder alimentar a su esposa, sus tres hijos y su suegra, pues la compañía de transportes en que trabajaba le había despedido y no tenía esperanzas de recibir la indemnización que fijaba la ley. Tras presentarse a cuantas ofertas de trabajo hallaba, un día se presenta a una oferta de La Sociedad Oriental de Importaciones y Exportaciones, situada en un lujoso edificio. Allí, tras entregar sus papeles, le hacen sentarse en espera de que el director le reciba. Entonces ve a otros dos hombres que también esperan nerviosos y ansiosos. Y, mientras les observa y los describe mentalmente, va pensando en quién logrará el puesto, pues eran sus "rivales", sus enemigos, en esa lucha por la vida. Mientras espera, recuerda también que esa semana ha mantenido entrevistas con una veintena de directores:

Había llamado a la puerta de todos los servicios imaginables. Había consultado pacientemente las ofertas de empleo de todos los periódicos... Incluso se había presentado para dirigir un palacio al borde del mar, pero, al subir las escaleras pisando la moqueta escarlata de la escalinata, había sentido que desentonaba en ese cuadro lujoso y había desandado el camino tragándose su humillación. Tenía absoluta necesidad de encontrar trabajo: empleado de escrituras en una sociedad, cajero en un cine, guardia municipal si hacía falta... Estaba gastando sus últimas cinco libras, todo lo que le quedaba de su salario. ¿Cómo iba a alimentar las cinco bocas a su cargo, cinco bocas ávidas que no se saciaban con toda una hogaza de pan...? Y, si él resistía el hambre, ¿cómo iba a pasarse sin su paquete de Bafra cotidiano? (Barbot, 1965: 71).

Mientras está en la sala de espera se da cuenta de que él era el único casado de los tres porque los otros dos no llevaban anillo. El que estaba a su lado era un hombre pálido, de ojos húmedos y largo rostro impenetrable y llevaba el pantalón recién planchado. Y el que tenía enfrente era un hombre más elegante que él, con una camisa inmaculada, corbata y zapatos brillantes, lo que le hace caer en que no ha dado cera a sus propios zapatos. Cree que el hombre elegante es el que tiene más posibilidades, pues los directores son sensibles a las apariencias y prefieren empleados con buena facha. Además fumaba Lucky Strike, sin ofrecérselo a nadie, y le miraba con altivez, lo que le causaba gran irritación. Sin embargo, piensa que, a pesar de su apariencia, buscaba trabajo como los demás y podía conseguirlo o no. Mientras tanto va pensando en la estrategia a seguir en

15 "Les ennemies", trad. de Barbot (1965: 69-74). 
la entrevista para lograr el trabajo. Había entregado con sus papeles su diploma de bachillerato, pero eso no le aseguraba nada, porque en otra entrevista con el director de una compañía aérea éste se había mofado de su título de un modo insultante. También debía recordar su experiencia de tres años en la compañía de trasportes, omitiendo que le habían despedido...

Cuando se abre la puerta, hacen pasar al candidato más elegante, y entonces piensa que ése será el elegido por el director... y se desespera pensando que no puede volver a casa con las manos vacías tras haber desgastado sus pobres suelas en busca de trabajo... Finalmente la secretaria le hace pasar... Y, acabadas las entrevistas, los tres se alinean frente al lujoso escritorio de caoba tras el que el director revisaba sus papeles, y les iba repasando con la mirada mientras se fumaba un cigarrillo... El ansioso protagonista deseaba que el director emitiera su veredicto, diciéndose:

“iVenga, di a quién has elegido...! ¿A este señorito, esa espátula de cara de caballo? No prolongues más nuestro suplicio. Con tu rostro completamente vacío no nos digas que somos unos cretinos, vulgares seres inútiles que no merecemos vivir con menos de la mitad de lo que cuestan tus zapatos..."

El aguijón le daba punzadas. Quería decir algo, preguntar lo que guardaba esa mirada cuya insistencia le hacía sudar a chorros.

El director se decidió por fin a hablar:

- Voy a estudiar vuestras candidaturas, y mi secretaría contactará con vosotros cuando haya algo seguro.

Nadie dijo palabra. Sabían que podían rechazarlos de muchas maneras... [...] Se dieron la vuelta con un movimiento maquinal, y salieron por la puerta de picaportes brillantes como marionetas que hilos invisibles conducen a un mismo destino. Recorrieron el corredor, bajaron la escalera con los mismos pasos y se pararon en el umbral. Nuestro héroe, sosegado de repente, miró a sus compañeros. El más elegante tomó su paquete de Lucky y les ofreció un cigarrillo. Se dieron fuego unos a otros y, como no podían hacer otra cosa, se despidieron con un apretón de manos. Cada uno se fue por su lado entre el estrépito del tranvía que pasaba. Y el ruido de sus pasos se perdió, entre el rechinar de las calles y las llamadas de los vendedores ambulantes, en el barullo del gran ganado que buscaba su pasto (Barbot, 1965: 74-75).

En "Obsesiones" (Hawāâyis ${ }^{16}$, de $A l-s \bar{a}^{-} a$ wa-l-insān, se trata de nuevo el tema de la muerte. Una niña huérfana de padre, que acaba de perder a su madre, está internada en un orfelinato. Es costumbre que las huérfanas allí alojadas asistan a los entierros de los personajes ricos que mueren en el barrio, pues son los que pagan los gastos del orfanato, y la niña se viste para la ocasión:

Se había puesto por primera vez su uniforme azul, demasiado largo para ella, pero, como le había dicho la gobernanta, le quedaría bien en uno o dos

16 “Âme en peine", trad. de Barbot (1964a: 155-158). 
años, cuando creciera. Luego se había colgado la insignia del orfanato. Con su cuellecito oprimido por el cuello almidonado y calzada con unos pesados zapatones, esperaba al fondo del dormitorio lo que iba a acontecer. La gobernanta volvió y las puso en fila en el patio, donde esperaron de pie durante veinte minutos antes de ponerse en marcha.

Trató incluso de no levantar la cabeza, pues la gobernanta lo había prohibido. Pero oía a la gente, al pasar el triste cortejo, preguntar quién había muerto. Y comprendió que las niñas de azul no traspasaban la puerta del orfanato más que cuando alguien moría fuera (Barbot, 1964a: 157).

Durante el velatorio, la gobernanta la obliga a colocarse, junto a las otras niñas, en torno al lecho del muerto, a la cabecera del cadáver, lo que va a causarle una tremenda conmoción, una impresión muy distinta a lo vivido al morir su madre:

Cuando su madre la había dejado, no había más que una flor, una rosa roja que ella había cogido de la única maceta del balcón y había depositado en su seno maternal. ¡Y ese seno estaba caliente y palpitante! $Y$ por ello se negaba a creer que su madre pudiera morir. [...]

Pero hoy había visto a la Muerte. Había sentido su olor característico: el incienso, las flores, los cuerpos sudando de angustia y de pena... dos cirios agonizantes en la cabecera y los pies del muerto... un ataúd glacial abierto en un rincón de la habitación... y... y... esa máscara de cera, con los ojos vidriosos y los labios azules, sobre la almohada (Barbot, 1964a: 157-158).

En casa de su abuela la niña había soñado que la madre muerta la visitaba en sueños, se sentaba a su lado y le hablaba, le sonreía y le daba algo... creyendo que había vuelto la vida. Pero ahora la imagen del entierro al que había asistido con las demás niñas del orfanato le va a producir pesadillas, especialmente de noche:

Desde la entrada en el orfanato no había vuelto a ver a su madre. El alma materna no frecuentaba más que los lugares familiares. Si no, la habría visitado esta noche y la habría librado de la obsesión que devoraba la tranquilidad de su infantil corazón (Barbot, 1964a: 158).

En "Porque él les ama" (Li-anna-hu yuhibbu-hum), de Al-sā'a wa-l-insān, hace una crítica descripción de la vida en un campo de refugiados de la UNRWA. Antes de la Nakba, Fayyāọ al-Ḥâŷy 'Alī era un buen labrador, que labraba su rica tierra, trabajaba duro para sustentar a su familia y estaba orgulloso de sus cualidades para la labranza y de la calidad sin rival de sus cosechas. La pérdida de Palestina le privó de su tierra, su única fuente de subsistencia, símbolo de su identidad y foco de su orgullo; tras la Nakba se había quedado sin nada, salvo sus sueños. En el campo de refugiados se da a la bebida para ahogar sus penas y escapar a la dura realidad de su opresiva existencia diaria, vendiendo la magra 
ración familiar que le daba la UNRWA para pagar su bebida. Un día su mujer embarazada -que era su prima y la mujer a la que amaba- trata de detenerle, y él la golpea hasta matarla. Él no era malo ni violento por naturaleza, pero fue llevado al crimen por fuerzas contra las que no pudo enfrentarse, siendo una víctima de las circunstancias que se le habían impuesto. Pero la gran perdedora y víctima fue su esposa, doblemente oprimida: por su identidad como palestina y por ser mujer en una sociedad machista.

En el campo hay también otro personaje, Abū Sālim, un refugiado traidor que se dedica a informar sobre los residentes en el campo a las autoridades de la UNRWA y, aunque es relativamente acomodado en comparación con la mayoría de los refugiados, tampoco duda en explotarlos. Los jefes extranjeros de la UNRWA siempre sospechan de sus desdichadas "cargas", y les disgusta cualquier actividad que huela a política, diciendo a los refugiados: "la política se para a las puertas de la oficina de la UNRWA" (Suleiman, 1991: 156). Esos jefes, que reciben pingües cheques mensuales, en vez de mejorar la calidad de vida de los refugiados tienen un sentido muy restringido de sus deberes, tratando las más simples peticiones -por ejemplo, la construcción de una escuela para reemplazar la inadecuada tienda escolar- como un acto de maliciosa agitación que podría tener incalculables implicaciones políticas. Piensan que la función de su organización es esencialmente la de ser una "cocina con sopa", por lo que alientan la dependencia y docilidad de los refugiados palestinos.

Por otro lado,el narrador de este relato es un empleado palestino de la UNRWA, que está por ello bien situado para conocer las condiciones que prevalecen en la organización, con toda la intolerancia, celos e intrigas que consumen la vida laboral de sus empleados, y para informar del desamparo, la desesperación, la docilidad y la dependencia que afligen a los refugiados. Y cuando su amigo Wașfí se pone a robar comida de los almacenes de la UNRWA sólo para su propio beneficio, este narrador decide prender fuego a los almacenes, como un desesperado acto de desafío contra las autoridades de la UNRWA y como un acto de amor hacia sus compañeros, los refugiados palestinos, que deben ser liberados de su sensación de abrumador desamparo que domina su indigente existencia. E1 narrador considera que este plan es un prerrequisito para que emerja una nueva era de orgullo en los antes orgullosos palestinos; no es un incendiario, sino un refugiado desesperado, que en sus momentos de más oscura desesperación ve la proverbial luz al final del túnel. Al incendiar los almacenes de comida trata simbólicamente de iniciar el proceso de animar a los refugiados palestinos del campo a deshacerse de la humillación de la dependencia que sufren a diario y a tomar el camino de la acción:

Yo te digo: ten hambre, para que tu desesperación te lleve a la rebelión. Así te alzarás definitivamente contra la mísera barra de pan [que la UNRWA te da por caridad] (Suleiman, 1991: 157). 
En este relato muestra el modo en que la Nakba afecta a las vidas de los refugiados, llevándoles a la violencia, la prostitución y el robo. Los palestinos, que son un pueblo orgulloso y tradicionalmente independiente, con la pérdida de la tierra pierden de repente su amor propio y su dignidad. Llevados por la desesperación y las duras realidades de la lucha por sobrevivir en un mundo golpeado por la penuria, se ven forzados a actuar de un modo totalmente ajeno a su carácter (Suleiman, 1991: 154-157).

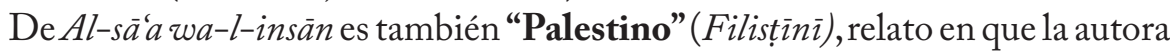
se centra en la vida de los refugiados palestinos en el Líbano. La separación de la familia y la patria, la dependencia de las magras raciones mensuales de la UNRWA, la pérdida de la familia, etc. inducen sentimientos de minusvalía y rechazo en los refugiados. En la diáspora, el apelativo "palestino" deja de ser un nombre de un grupo nacional para convertirse en una etiqueta estigmatizadora. Esta actitud por parte de los árabes de los países de acogida hacia sus hermanos palestinos está incisivamente descrita en este relato.

El protagonista, un tendero palestino que vive en una ciudad libanesa, siempre se topa con sospechas, cuando no con hostilidad, por la simple razón de ser palestino. La identidad palestina se convierte en la cruz con la que cargan allá donde vayan. Incluso cuando un palestino expresa su disposición a cambiar su identidad por la del país de acogida, le tratan como un indeseable y un leproso social (Suleiman, 1991: 160-161). Pero los refugiados pobres en busca de trabajo no son los únicos que conocen estas relaciones humillantes y discriminatorias, pues tampoco los de clase media pueden evitarlas, como es el caso del fracaso de este tendero palestino en su esfuerzo por integrarse en el país de acogida (Ballas, 1980: 50):

En el barrio donde está situada su tienda -tienda que en nada se diferencia de las otras- él no es más que "el palestino". Es identificado como "palestino". Le señalan con el dedo en tanto que "palestino" y, eventualmente, le insultan al tratarle como "palestino". Es como el zapatero armenio que pasaba toda su vida reparando los zapatos de sus vecinos sin que nadie hubiera buscado saber si se llamaba Hayep, Sarkis o Artin. "El armenio" era todo su nombre (Ballas, 1980: 50).

En sociedades tan hostiles como es en ese momento la libanesa, una tarjeta de identidad (ID) les parece a algunos refugiados palestinos el único camino para mejorar su vida en el exilio, aunque cada vez es más costoso y humillante el proceso para conseguirla, como dice el narrador aludiendo a un palestino exiliado:

Ahora eran mucho más [de 200 liras por una ID libanesa]...Hace algunos años él habría rehusado pagar una cuarta parte de esa cantidad para sacar a la luz a un abuelo de una adecuada aldea libanesa o resucitar una nueva 
historia completa de su abuelo Abū Ṣālị que, por lo que sabía, había nacido y muerto en al-Rāma. No le hubiera negado tres veces antes de cantar el gallo, pero quizás hubiera pedido su permiso para hacer uso de una coincidencia geográfica que podría evitarle la palabra "palestino", palabra que le ligaba a una casta en que todo signo de individualidad había sido borrado. La palabra se pronunciaba con compasión, pero él rechazaba ser objeto de compasión. [...] Una nube de ansiedad le hizo sentir como si él, su tienda, sus cuatro hijos y su esposa fueran meros juguetes con los que se entretenían aquellos intérpretes de los acontecimientos. Su única garantía contra lo desconocido en una múltiple deportación era convertirse en naturalizado (Taha, 2010: 54).

En "E1 ave-rock de Šaharbān" (Ṭayr al-rujj fī Šaharbān ${ }^{17}$, de $A l-s \bar{a}^{\prime} a$ wa-linsān, relata un suceso auténtico: una inquisición aldeana en el Iraq de la Gran Guerra y la revuelta silenciosa de las masas contra el oscurantismo criminal de un tirano de mezquita. El joven Rādīi, al que todos creían muerto por el hambre o el frío porque le habían robado el capote para protegerse de la ventisca, había decidido no morir y había desertado del ejército turco en el Cáucaso durante la primera guerra mundial. Tras largos años de atravesar fronteras, logra regresar a su aldea natal en Iraq, y una noche llama a la puerta de su humilde choza acurrucada al pie de las palmeras. La noticia se expande rápidamente, y todos se reúnen para celebrar la vuelta del superviviente, deseando escucharle contar su odisea. Rāḍī les cuenta las cosas que había visto en ese tiempo, pensando que no le van a creer:

- He visto carros de hierro que se enganchaban unos a otros, tirados por el más grande de ellos sobre dos hilos brillantes más afilados que el Puente del Juicio Final.

Los ojos se abrieron desmesuradamente, y las miradas se cruzaron entre el estupor general $[\ldots]$.

- Y eso no es todo [...]. Hay algo aún más increíble: pequeños carruajes que marchaban, no importa dónde, con dos ojos brillantes que se encendían y apagaban solos, transportando a cinco o seis personas a la vez, y que iban a toda marcha gritando: ${ }_{\text {CCuidado! }}$ Cuidado!

Esto era demasiado para mi pobre tía, que exclamó con la cafetera en la mano:

- Mi pequeño Rāẹī, estás fantaseando. Tengo miedo de que...

- ¡Por tu vida, tía, no estoy diciendo más que la verdad! Y eso no es todo. He visto un pájaro inmenso, más grande que el ave-rock, cuyo grito estremecía a todo el país. ¡Y creíamos que el cielo se abatía sobre nosotros! [...]

- Mi pobre Rādīi, si el šayj te oyera, te tomaría por loco.

Ella parecía ya presentir el drama que seguiría (Barbot, 1965: 57-58).

En efecto, esa noche habían acudido a la velada varios discípulos de un retrógrado šayj que mascullaban exorcismos al oír aquellos relatos, y se lo fueron

17 "L'oiseau rock de Shéherban", trad. de Barbot (1965: 55-60). 
a contar citando con horror aquellas blasfemias... El šayj tenía un tratamiento para cualquier impiedad, física o mental, una respuesta para los males de aquella pobre gente, para exorcizar los demonios, curar a una retrasada o a una mujer estéril, como bien sabían los enfermos: lecturas de textos sagrados, encantamientos, talismanes, bastonazos... El šayj decretó que Rāẹī "era un loco que repetía lo que le decían los demonios” y, mientras Rādī mantenía que era verdad lo que había visto, mandó aplicarle su tratamiento de bastonazos:

Razzūq trajo unos sólidos garrotes de madera de granado mojados de agua para hacerlos más eficaces. Cuatro acólitos devotos los empuñaron, puestos en posición. Y los golpes empezaron a llover como granizo. "Veinte más... Otros veinte... Veinte..... [...]

Los bastones hendían el aire, mientras la verdad bramaba en la garganta del desdichado, que con el tiempo ya fue incapaz de cualquier locura o impiedad. Entonces sus restos fueron llevados en cortejo a su tía (Barbot, 1965: 59).

Pero poco después los soldados turcos habían abandonado los altos de la aldea, y supieron que los ingleses se estaban aproximando por el norte. Poco a poco unos y otros fueron viendo por la zona esos trenes, camiones y aviones de los que había hablado Rāẹī...La gente de la aldea se fue reuniendo irritada por lo que había hecho el šayj con Rãdị, y en silencio se levantaron unos cuantos hombres, incluidos algunos de sus discípulos, para hacer justicia con el šayj, mientras los demás escuchan sus alaridos infernales muertos de espanto, escena con la que comienza el relato.

En "La herencia" $(A l \text {-tarika })^{18}$, de $A l$-sāa $w a-l$-insān, denuncia la avaricia humana. El narrador es un vecino de Abū Nāṣîf, comerciante lleno de achaques cuya familia está deseando que fallezca, pero que siente placer en tenerlos a todos en ascuas. Como no salía de la cama, su almacén lo llevaba su esposa. Y, como no tenían hijos, el hermano, la hermana y otros familiares esperan heredarle, dispuestos a revocar un testamento a favor de su esposa, aduciendo que estaba loco. Además montaban guardia ante el almacén para evitar que la esposa sacase cosas a sus espaldas, y le hacían visitas interesadas a la espera de la herencia. Por otro lado, los familiares de la esposa también lo vigilaban para evitar que ella fuera privada de la herencia. Pero un día los vecinos observan con asombro que los familiares han dejado de espiar el almacén:

Vimos que el puesto de vigilancia estaba desocupado todo un día, y luego dos... Y supimos que el hermano, aquel engendro calvo, tuvo escrúpulos y decidió no disputar la herencia a su cuñada. Había convencido a sus hermanas y maridos de que esas mezquindades serían mal vistas por los vecinos y que, a fin de cuentas, esa mujer, tras toda la agonía que había sufrido, tenía derecho a disfrutar de lo que se había merecido (Barbot, 1964a: 154).

18 "Le magot", trad. de Barbot (1964a: 153-155). 
Los vecinos toman la postura de aquel engendro rechoncho, bajito y más calvo que un huevo, como un gesto de caballerosidad. Pero, cuando por fin Abū Nāṣif muere, su viuda vuelve a su rutina en el almacén durante un tiempo, hasta que el vecindario descubre un día que el almacén ha cerrado:

Esto suscitó nuestra perplejidad, y más cuando la casa de la viuda mantenía las persianas cerradas. A Dios gracias, pronto pudimos conocer el final de esta historia al ver una tarde a nuestra tierna y gruesa vecina subir la escalera del brazo de un hombre pequeño...

"iSe ha casado con ella!" (Barbot, 1964a: 155).

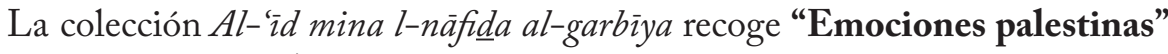
(Wiŷdānìyāt filisținnìya), donde reúne 25 fragmentos breves que parecen escritos justo tras dejar Acre en 1948, lo que puede explicar la expresión de tantos sentimientos, sueños, anhelos y nostalgia de Acre, ciudad donde la autora había nacido y pasado la mitad de su corta vida (Taha, 2010:54). En esos fragmentos se ofrece un penetrante análisis de la situación en que se encuentran los refugiados palestinos al perder su "patria" tras la Partición, su traumática experiencia de desamparo y envilecimiento, así como sus esperanzas y aspiraciones, que se concentran en el retorno como objetivo nacional último y la única solución que les puede devolver su dignidad. La ligazón de los refugiados con su tierra es genuina, está hondamente sentida y se sostiene a través de sus recuerdos, que remiten a una rica tierra, a una gente feliz que vive en armonía con los otros, sin tener en cuenta la afiliación religiosa. Estas percepciones están tratadas con ternura, convicción y, como era de esperar, con frecuentes explosiones de sentimientos que reflejan de verdad el espíritu de los refugiados (Suleiman, 1991: 163).

Los peligros de la desposesión y dispersión que amenazan las vidas de los refugiados los representa con la imagen del "cuervo", que en la cultura tradicional palestina significa "muerte", "destrucción” y "separación”, o con la "serpiente", con sus fuertes connotaciones bíblicas de siniestra maquinación y conductas de duplicidad, denotando con ambos la calamidad que cayó sobre Palestina y su pueblo en 1948.

Varios fragmentos describen la belleza y fertilidad de Palestina, un "microcosmos de todo el universo". En los ojos y la memoria de los refugiados, Palestina es "una tierra de leche y miel", que está cubierta de olivos, higueras, almendros, vides y campos de naranjos cuyo perfume y flores añaden color y fragancia a la tierra, que no es un desierto vacío:

[La llanura costera] consiste en un naranjo tras otro, un campo de naranjos junto a otro, un vergel junto a otro, formando un gran jardín que pertenece a todos y cada uno (Suleiman, 1991: 162-163). 
En la mente de los refugiados Palestina permanece leal a su pueblo disperso, en amor y lealtad recíproca. En un fragmento, que refleja la situación de Palestina tras la ocupación, un anciano refugiado narra que un almendro pierde sus flores y se niega a dar fruto hasta que vuelvan sus legítimos propietarios, mientras que la vida vibra en sus raíces como anticipo del retorno de su pueblo y de que volverá a emerger la vida:

Me dijeron que esa primavera les había faltado a los niños el almendro, paraguas de blancas estrellas. Las esperaban en las mañanas y noches de primavera, deseando que lloviesen sus blancas estrellas sobre ellos, pero nunca aparecieron en el jardín. No había flores blancas, y las ramas habían perdido sus hojas una a una, $[\ldots]$ como si fuera otoño (Piselli, 1988: 102).

Pero otros árboles siguen saludables, dispuestos a dar frutos cuando retorne su gente. Esa empatía entre la tierra y el pueblo los sostiene a ambos en su mutua separación. La idea del retorno ('awda) encierra una paradoja entre desposesión y dispersión, por un lado, y esperanza y fuerte deseo de unidad entre la tierra y su pueblo, por otro. También significa un pacto entre la vieja generación de palestinos, que vivieron en Palestina, y la joven generación, que ha sido privada de esa experiencia. Por ello varios fragmentos describen a la vieja generación trasmitiendo su rico repertorio de recuerdos, como un legado nacional, a los jóvenes, que escuchan esas historias que han de preservar y transmitir hasta que se produzca el retorno.

Los refugiados están absortos en su visión del regreso, con el que sueñan día y noche. Se describen como pájaros que vuelan sobre sus aldeas y ciudades inspeccionando sus casas y sus campos, y se preguntan dónde vivirán cuando se realice su sueño de retornar. El retorno impregna cada aspecto de la vida de los refugiados -su conciencia, sus tiendas de campaña, sus casas y el aire que respiran- y es muy real, aunque aún no se haya producido: una cajita de madreperla, un grabado de madera de olivo de Belén o un mantel tradicional bordado a mano con ricos dibujos palestinos se convierten en sinónimos de la tierra perdida y del querido y largamente esperado sueño del retorno (Suleiman, 1991: 161-164). Los objetos importantes de la historia de una familia palestina podían estar guardados en un armario, cuya llave simboliza la idea del retorno:

Mi madre había llevado la llave de esa armario lejos, muy lejos, porque estaba tan segura, como que el cielo es azul, de que un día volvería a encontrar ese armario e inscribir en su puerta, con otro lápiz, una fecha inolvidable: la fecha del retorno (Piselli, 1988: 103).

Y en otro fragmento la autora anima a los palestinos a trabajar por ese retorno, idea clave de estas "Emociones palestinas": 
Limpia tus lágrimas, hermano, porque ellos no estarán mucho tiempo. Ante ti una tierra te espera. Las lágrimas no volverán a ti. [...] Palestina suspira por tus acciones, tus esfuerzos, tu lucha y tu fe. [...] ¡Así que trabaja por su causa! (Piselli, 1988: 104).

\section{CONCLUSIÓN}

Para concluir, podemos recoger las valoraciones que realizan algunos de los críticos que han estudiado y traducido relatos de Samīra 'Azzām, relatos que le han otorgado una destacada posición en la literatura árabe y palestina.

Según Miriam Cooke (1992: 452), Samīra ha sido descrita como un puente entre la antigua generación de escritores palestinos y la diáspora en general, y señala que sus obras se centran en la opresión económica y social sufrida por todos los miembros de la sociedad palestina.

Abū Fajr (2012) la considera pionera del relato corto (rä̉idat al-qișșa alqașira) en Palestina, al igual que Radwa Ashour (2008: 220-221), que también señala que Samīra escribe historias con una estructura coherente, basada en la unidad de acción y en la economía del lenguaje, y que se centran en la gente común, en sus preocupaciones cotidianas y su experiencia con distintas formas de represión, sea económica, social o nacional; declara que Samīra es "la poetisa de las ansiedad cotidiana de todos los tamaños. Los niños pequeños están ocupados por pequeños problemas, que son los típicos que colorean su mundo; y los problemas de los adultos son tan grandes como todo su mundo"; y añade que escribe sobre gente "que responde a los ataques de una sociedad clasista y muy hostil que aplasta a aquellos que están en medio del conflicto".

Para Piselli (1988: 93), la obra de Samīra evoluciona desde relatos simples y personajes esquemáticos a personajes de un desarrollo más complejo y a un uso de su narrativa más rico, incluyendo el simbolismo y el reflejo de temas más universales.

Abu Nakr (cit. en Taha, 2010: 52) afirma: "No hay duda de que Samīra 'Azzām es una pionera del moderno relato palestino". E Ibrahim Taha (2010: 52, 56-57) cree que Samīra jugó un papel significativo en la ficción palestina de mediados del s. XX, en general, y en el moderno relato palestino en particular; considera que su contribución literaria se puede hallar en dos niveles diferentes: en la escritura literaria original y en la traducción literaria; y señala que Samīra es la primera autora palestina en centrarse en los temas femeninos, fundando así una nueva tendencia en la literatura palestina, "la literatura de mujeres", y también que creía firmemente en el poder de las palabras y en su papel clave en la existencia humana, algo que es especialmente urgente cuando un pueblo se siente amenazado y está hondamente comprometido en una batalla sin fin por sus derechos. 


\section{BIBLIOGRAFÍA}

AвŪ FAJR, Șaqr, (2012): "Samīra 'Azzām adība mubdi'a wa-šāīirīya mutawāriya”. http://palestine.assafir.com/Article.aspx?ArticleID=2271

Ashur, Radwa, Ghazoul, Ferial J. y Reda-Mezdashi, Hasna (eds) (2008): Arab Women Writers. A Critical Reference Guide. 1873-1999. Cairo-New York: The American University in Cairo Press.

'Azż̄à, Samīra (1971): "Entrevista con Mijā̄îl Na'īma”, trad. de Avelina Cobos, Almenara, 1, 79-83.

Ballas, Shimon (1980): Le Littérature arabe et le conflit au Proche-Orient. 1948-1973. Paris: Éditions Anthropos.

Barbot, Michel (1964): "Destins de femmes arabes", Orient, 31, 109-128.

Bаввот, Michel (1964a): "Satire et pitié sociales chez Samira 'Azzam”, Orient, 32-33, 149-170.

Barbot, Michel (1965): "Nouvelles stridentes", Orient, 34, 51-74.

Сооке, Miriam (1992): "Arab Women Writers", en Badawi, M. M. (Ed.): Modern Arabic Literature, Cambridge: Cambridge University Press, 443-462.

Descamps-Wassif, Sara, Cortet, Eveline y Berrada, Fatima (1999): Dictionnaire des écrivains palestiniens/Muìam al-kuttäb al-filisținnìyinn. Paris: Institut du Monde Arabe.

Farag,Joseph R.; Ouyang, Wen-Chin; Beard, Michael; Parr, Nora E. (2015): "Samira 'Azzam's 'Man and His Alarm Clock', Middle Eastern Literatures, 18, 1, 86-92.

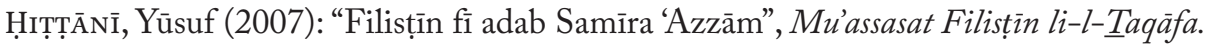
http://www.thaqafa.org/site/pages/details.aspx?itemid=6327\#.VwosaY9OLIU

IskANDAR, Fārūq Yūsuf, 2011: "Samīra 'Azzām...rā’ida". http://alhourriah. org/article/1458/\%D $\%$ ED \%DD-\%D 3\%C 7\%CE\%E4-\%DD\%ED\% C $3 \%$ C C \% E $6 \%$ C 7 \% C 1 - \% E $3 \%$ E 4 - \% C $7 \%$ E $1 \%$ C D \% D 1\% C 8 $\% \mathrm{C} 7 \% \mathrm{E} 1 \% \mathrm{C} 8 \% \mathrm{C} 7 \% \mathrm{D} 1 \% \mathrm{CF} \% \mathrm{C} 9 . \mathrm{html}$

JaYYusi, Salma Khadra (1992): Anthology of Modern Palestinian Literature. New York: Columbia University Press.

Khalil-Haвib, Nejmeh (s.d.): "Samira Azzam (1926-1967): Memory of the Lost Land”. http://www.nobleworld.biz/images/samiraazam.pdf

Makarius, Raul y Makarius, Laura (1964): Anthologie de la littérature arabe contemporaine. Le roman et la nouvelle. Paris: Éd. du Seuil.

Manzalaoui, Mahmoud (1989): Arabic Short Stories. 1945-1965. Cairo: The American University in Cairo Press.

Piselli, Kathyanne (1988): “Samira Azzam: Author's Works and Vision”, International Journal of Middle East Studies, 20, 1, 93-108.

Suleiman, Yasir (1988): "Fate', by Samīra 'Azzām”, Journal of Arabic Literature, 19, 2 , 142-148.

Suleiman, Yasir (1989): “I Want Water', by Samīra 'Azzām”, Journal of Arabic Literature, 20, 2, 164-167.

Suleiman, Yasir (1990): “Until Such a Time', by Samīra 'Azzām”, Journal of Arabic Literature, 21, 2, 183-189. 
Suleiman, Yasir (1991): "Palestine and the Palestinians in the Short Stories of Samīra 'Azzām”, Journal of Arabic Literature, 22, 2, 154-165.

Tана, Ibrahim (2010): “Samīrah 'Azzām (1927-1967)”, en Allen, Roger (Ed.): Essays in Arabic Literary Biografy. 1850-1950. Wiesbaden: Harrassowitz Verlag, 51-57.

Thomas, Clara Ma, 2008: "En memoria de la poetisa Fadwa Tuqán, símbolo de la resistencia palestina”. Arriaga, Mercedes y otros. De lo sagrado y lo profano. Mujeres tras/ entre/sin fronteras. Sevilla, Arcibel, 517-542.

Viguera, Ma Jesús y Villegas, Marcelino (1969): Narraciones árabes del siglo XX. Ed. Magisterio Español. Madrid.

http://arabic.jadaliyya.com/pages/index/13958/\%D9\%85\%D9\%84\%D9\%81\% D $9 \% 85 \%$ D $9 \% 86$ - \% D 8\% A 7 \% D 9\% 8 4\% D 8\% A 3\% D 8\% B 1\% D 8\% B $4 \%$ D $9 \% 8$ A \% D 9\% 81 _\% D 8\% B 3\% D 9\% $85 \%$ D 9\% 8 A \% D 8 \% B 1\% D 8\%A9-\%D8\%B9\%D8\%B2\%D8\%A7\%D9\%85

Nombre del autor: Clara $\mathrm{M}^{\mathrm{a}}$ Thomas de Antonio

Dirección-e: cthomas@us.es

Dirección postal: Facultad de Filología. Área de Estudios Árabes e

Islámicos.

c/ Palos de la Frontera s.n.

41004 Sevilla

Fecha de recepción: 05/02/2015

Fecha de aceptación: 28/06/2016 